\title{
Tingkat Kecukupan Modal, Pertumbuhan Kredit, dan Risiko Operasional Pada Profitabilitas Lembaga Perkreditan Desa
}

\author{
Kadek Darmawan ${ }^{1}$ \\ I Wayan Suartana ${ }^{2}$
}

${ }^{1}$ Fakultas Ekonomi dan Bisnis Universitas Udayana (Unud), Bali, Indonesia
email: darmawandekco@ gmail.com / Telp: 081353339991
${ }^{2}$ Fakultas Ekonomi dan Bisnis Universitas Udayana (Unud), Bali, Indonesia

\begin{abstract}
ABSTRAK
Pembangunan nasional berfokus pada masyarakat pedesaan yang berperan penting dalam kegiatan ekonomi di pedesaan yang kegiatan pembiayaan dan perkreditan dilakukan untuk menunjang pembangunan. Salah satu upaya Pemerintah Provinsi Bali untuk mendukung perkembangan perekonomian masyarakat desa adalah dengan mengembangkan lembaga keuangan bagi masyarakat pedesaan yang dikenal dengan Lembaga Perkreditan Desa. Penelitian ini dimaksudkan untuk mengetahui apakah kecukupan modal, pertumbuhan kredit, dan risiko operasional berpengaruh terhadap kemampuan LPD di Kabupaten Gianyar dalam memperoleh laba di tahun 2015-2017. Untuk menjawab permasalahan tersebut penelitian ini menggunakan 213 sampel data dan teknik analisis data yaitu regresi linear berganda. Bersadarkan hasil analisis regresi berganda, diketahui bahwa hasil uji $\mathrm{F}$ dan Hasil uji t menunjukkan bahwa kecukupan modal, dan pertumbuhan kredit berpengaruh positif dan risiko operasional berpengaruh negative pada profitabilitas Lembaga Perkreditan Desa (LPD) di Kabupaten Gianyar periode 2015-2017.
\end{abstract}

Kata Kunci : CAR, BOPO, ROA, profitabilitas

\begin{abstract}
National development focuses on rural communities who play an important role in economic activities in rural areas where financing and credit activities are carried out to support development. One of the efforts of the Provincial Government of Bali to support the economic development of rural communities is by developing financial institutions for rural communities known as the Lembga Perkreditan Desa. This study is intended to find out whether capital adequacy, credit growth, and operational risk affect the ability of LPDs in Gianyar Regency to earn profits in 2015-2017. To answer these problems this study uses 213 data samples and data analysis techniques, namely multiple linear regression. Based on the results of multiple regression analysis, it is known that the $F$ test results and t test results show that capital adequacy, and credit growth have a positive effect and operational risk has a negative effect on the profitability of the Village Credit Institution (LPD) in Gianyar Regency for the 2015-2017 period.

Keywords: CAR, BOPO, ROA, profitability
\end{abstract}

\section{PENDAHULUAN}

Pembangunan nasional berfokus pada masyarakat pedesaan yang berperan penting dalam kegiatan ekonomi di pedesaan yang kegiatan pembiayaan dan perkreditan dilakukan untuk menunjang pembangunan (Matrisyasi, 2010). Peningkatan sektor keuangan sangatlah penting untuk pertumbuhan ekonomi. Salah satu upaya yang 
Kadek Damawan dan I Wayan Suartana. Tingkat...

ditempuh Pemerintah Provinsi Bali untuk mendukung perkembangan perekonomian masyarakat pedesaan adalah dikembangkannya lembaga keuangan di lingkungan masyarakat pedesaan yang dikenal dengan Nama Lembaga Perkreditan Desa (LPD). Lembaga Perkreditan Desa adalah salah lembaga keuangan non-bank yang memiliki dasar hukum yang berbeda dengan Bank. LPD menggunakan Peraturan Daerah (PERDA) Provinsi Bali No. 2 tahun 1998, sedangkan bank menggunakan Undang-undang No. 7 tahun 1992 tentang perbankan sebagai dasar hukumnya.

Lembaga Perkreditan Desa diperkuat di bawah payung hukum peraturan Daerah (Perda) Provinsi Bali No. 2 tahum 1988 yang kemudian dirubah dengan Perda No. 8 tahun 2002. Regulasi Perda terkini yang mengatur LPD adalah Perda No. 4 tahun 2012. Meskipun peraturan mengalami perubahan, estimasi LPD tidak pernah berubah khususnya dalam hal kepemilikan, karena LPD satu-satunya lembaga keuangan mikro yang dimiliki oleh kmunitas adat dengan sistem bebanjaran khas bali. Menurut Eka (2011), Keberadaan LPD diakui memberi manfaat ekonomi yang sangat besar oleh Desa pakraman dalam kaitan dengan fungsi perekonomian dan pengembangan kebudayaan.

Surata (2011) menyatakan Lembaga Perkreditan Desa (LPD) memiliki beberapa tujuan yaitu, untuk mendorong pembangunan ekonomi masyarakat Desa melalui tabungan yang terarah serta penyaluran modal yang efektif, memberantas sistem ijon, gadai gelap, dan lain-lain yang bisa disamakan dengan itu di daerah pedesaan, dapat menciptakan pemerataan dan kesempatan kerja bagi warga pedesaan, serta menciptakan daya beli dan melancarkan lalu lintas pembayaran 
dan pertukaran di Desa. Peran lainnya dari LPD yang tidak kalah penting adalah kemampuan dalam menghasilkan laba yang menjadi sumber pembiayaan pembangunan desa adat. Tugas dan usaha LPD diarahkan untuk meningkatkan taraf hidup kelompok masyarakat pedesaan.

Melihat pentingnya peranan LPD yang mampu menunjang perekonomian masyarakat Desa maka kinerja LPD pada saat ini harus lebih mendapat perhatian. Penilaian kinerja LPD tidak lepas dari kemampuannya dalam menghasilkan laba yang merupakan salah satu indikator kinerja perusahaan. Kemampuan perusahaan menghasilkan laba dalam satu periode atau setiap periode tertentu disebut dengan Profitabilitas (Samina, 2013). Laba dapat diperoleh dari pendapatan yang merupakan total manfaat yang dihasilkan oleh semua infrastuktur perusahaan (Bratland, 2010). Profitabilitas dalam penelitian ini diproksikan dengan Return On Asset (ROA), karena Return On Asset (ROA) memanfaatkan modal sendiri untuk memperoleh keuntungan dan digunakan untuk menjadi tolak ukur kemampuan seuatu perusahaan dalam memperoleh laba dengan memamfaatkan total aktivaaktiva yang dimilikinya (Agustiningrum, 2013). Return On Asset merupakan proksi dari profitabilitas yang lebih penting dibanding proksi yang lainnya. Tingkat Return On Asset yang tinggi pada bank menunjukan tingkat return yang diterima oleh bank juga tinggi. Semakin besar pertumbuhan Return On Asset menunjukan profitabilitas bank semakin baik karena setiap aktiva yang dimiliki dapat menghasilkan return, sebaliknya nilai Return On Asset yang negatif mencerminkan profitabilitas yang negatif atau rugi. Usaha pada LPD harus 
dilakukan secara effisien, efektif, dan ekonomis untuk mencapai keuntungan yang optimal (Nila dan Suartana, 2009).

Demi melancarkan kegiatan operasional suatu lembaga keuangan, sangat penting untuk memiliki permodalan yang cukup atau banyak (Siamat, 2001: 100). Modal merupakan faktor penentu utama dalam kapasitas pinjaman oleh lembaga keuangan, karena modal tersebut merupakan bertujuan untuk menciptakan keseimbangan dan menyerap kerugian, serta dapat menjaga kepercayaan nasabah (Oktaviani, 2012). Ukuran yang digunakan untuk menilai kecukupan modal adalah Capital Adequacy Ratio (CAR). CAR menunjukan rasio kecukupan modal lembaga keuangan dalam menjalankan proses kegiatannya. Menurut Vong dan Chan (2009) menunjukkan bahwa kekuatan modal dari suatu lembaga keuangan sangat penting dalam mempengruhi profitabilitas.

Perkembangan LPD tidak lepas dari kesuksessan dalam penyaruran kredit kepada masyarakat yang nantinya digunakan sebagai modal dalam berusaha. Menurut Hakim (2009) pertumbuhan kredit merupakan jumlah dari pertumbuhan aktiva produktif yang dalam hal ini adalah kredit yang merupakan penyerahan uang dari kreditur/pemberi pinjaman kepada debitur/penerima pinjaman atas dasar kepercayaan dengan janji membayar pada tanggal yang telah disepakati oleh kedua pihak. Pertumbuhan kredit dalam penelitian ini diproksikan dengan rasio LDR.

Lembaga keuangan sebagian besar sangat memegang peranan penting dalam mendukung perkembangan perekonomian yang ada di Indonesia. Perusahaan akan menghadapi risiko dan tantangan yang semakin sering akan 
terjadi. Risiko dan tantangan ini dapat terjadi dikarenakan perusahaan ingin mencapai tujuan yang telah ditetapkan, salah satunya mencapai laba maksimal (Ariestya dan Ardhana, 2016). Untuk memenuhi kebutuhan operasionanya, perusahaan harus mampu memperoleh dana dari berbagai pihak. Kebutuhan pendanaan dapat diperoleh melalui dalam perusahaan (internal financing) dan dari luar perusahaan (eksternal financing) (Priyono, 2012). Jika suatu LPD terlalu banyak mengambil danadari luar maka akan mengakibatkan utang yang dapat menghambat perkembangan suatu LPD yang pada nantinya akan membuat keengganan pemegang saham atau nasabah untuk menanamkan modalnya (Brigham dan Houston, 2006). Purwanto (2011:3) menyebutkan ada beberapa faktor yang berpengaruh terhadap profitabilitas Lembaga keuangan yaitu: melemahnya nilai tukar rupiah, lemahnya kondisi internal bank, seperti manajemen yang kurang memadai dan pemberian kredit kepada kelompok atau group usaha sendiri telah mendorong tinginya risiko kredit macet, tingkat kompleksitas usaha yang tingi akan mengakibatkan risiko yang dihadapi oleh bank dan modal yang tidak dapat menutupi terhadap risiko-risiko yang dihadapi oleh bank tersebut menyebabkan kinerja bank menurun.

Lembaga Perkreditan Desa (LPD) hampir sama dengan perbankan. Pengelolaan LPD dengan perbankan hampir sama yakni menghimpun dana dari masyarakat (anggota LPD) dan kemudian menyalurkan dalam bentuk pinjaman kepada masyarakat yang membutuhkan (anggota LPD) dalam hal ini menunjukan bahwa Lembaga Perkreditan Desa (LPD) sudah selayaknya mempunyai kemampuan dalam hal manajemen risiko atau sudah mengikuti program sertifikasi 
manajemen risiko. Tentunya konsep yang ditawarkan disesuaikan dengan tingkat risiko yang melekat pada Lembaga Perkreditan Desa (LPD) tersebut.

Efisiensi operasional merupakan kemampuan LPD dalam memanfaatkan dana yang dimiliki dengan biaya yang dikeluarkan untuk mengoperasikan dana tersebut. Efisiensi operasional LPD dapat dilihat dari rasio Biaya Operasional pendapatan Operasional (BOPO). BOPO merupakan rasio yang digunakan untuk mengukur kemampuan manajemen LPD dalam mengendalikan biaya operasional terhadap pendapatan operasional (Edhi, 2012). Semakin rendah BOPO maka semakin efisien Lembaga Perkreditan Desa (LPD) tersebut dalam mengendalikan biaya operasionalnya, dengan adanya efisiensi biaya maka keuntungan yang diperoleh LPD semakin meningkat (Lukma, 2005).

Penelitian mengenai LPD ini dilakukan, karena LPD mempunyai keunikan tersendiri yaitu hanya terdapat di Bali dan mempunyai peran dalam masalah keuangan masyarakat desa pakraman di Bali (Sudiantari, 2011). LPD jika dibandingkan dengan lembaga keuangan lainnya yaitu merupakan suatu bentuk lembaga keuangan yang bersifat sangat khas dan khusus dilihat dari dasar konstitusional, dasar hukum, asal-usul dan tujuan, serta pola kerja yang sangat berbeda dengan lembaga keuangan lainnya (Nurjaya dalam Landasan Teoritik Pengaturan LPD, 2011:77). Kabupaten Gianyar merupakan salah satu kabupaten dengan jumlah LPD yang besar. Jumlah LPD yang terdapat di Kabupaten Gianyar sebanyak 269 LPD tersebar dalam 7 Kecamatan. 
Tabel 1.

LPD di Kabupaten Gianyarsampai 2017

\begin{tabular}{cll}
\hline No & Nama Kecamatan & Jumlah LPD \\
\hline 1 & Blahbatuh & 36 \\
2 & Gianyar & 40 \\
3 & Payangan & 48 \\
4 & Sukawati & 33 \\
5 & Tampaksiring & 36 \\
6 & Tegalalang & 44 \\
7 & Ubud & 32 \\
\cline { 2 - 2 } Sumber:LPLPD Kabupaten Gianyar, 2018
\end{tabular}

Berdasarkan hasil penelitian sebelumnya, yaitu penelitian yang dilakukan oleh Exsiani (2010) menyatakan bahwa kecukupan modal berpengaruh signifikan terhadap profitabilitas LPD, sedangkan penelitian oleh Obicks (2010) dan Prasetyo (2012) mengatakan bahwa kecukupan modal tidak berpengaruh terhadap profitabilitas. Penelitian Pramartha (2018) dan Rastiniyati (2015) menyatakan bahwa pertumbuhan kredit berpengaruh terhadap profitabilitas. Penelitian yang dilakukan oleh Yuliani (2007), dan Yogi (2013) yang menyatakan bahwa risiko Operasional berpengaruh terhadap profitabilitas sedangkan penelitian yang dilakukan oleh Taufik (2011) menunjukan hasil yang berbeda. Perbedaan hasil penelitian tersebut menjadi menjadi suatu kesenjangan(research gap).

Tujuan penelitian ini yakni untuk mengetahui dan membuktikan seara empiris pengaruh kecukupan modal pada profitabilitas LPD di Kabupaten Gianyar, mengetahui dan membuktikan seara empiris pengaruh pertumbuhan kredit pada profitabilitas LPD di Kabupten Gianyar serta untuk mengetahui dan membuktikan seara empiris pengaruh risiko operasional pada profitabilitas LPD di Kabupten Gianyar. Penelitian ini diharapkan mampu memberikan pemahaman mengenai pengaruh kecukupan modal, pertumbuhan kredit, dan 
manajemen risikopada profitabilitas LPD. Selain itu penelitian ini memberikan gambaran mengenai penerapan teori stewardship dalam ruang lingkup LPD. Hasil penelitian ini juga diharapkan dapat menjadi referensi bagi para pengelola LPD dalam upaya memaksimalkan pertumbuhan profitabilitas sebagai salah satu tujuan perusahaan. Kegunaan praktis yang dihasilkan dalam penelitian ini antara lain, penelitian ini diharapkan dapat menjadi referensi bagi LPD dalam mengidentifikasi variabel yang dapat mempengaruhi profitabilitas dalam menentukan kebijakan yang berkaitan dengan profitabilitas agar dapat diperoleh penggunaan modal yang tepat.

Adapun kerangka konseptual dalam penelitian ini menunjukkan pengaruh antar variabel dalam penelitian. Kerangka konseptual dalam penelitian ini disajikan pada gambar 1 sebagai berikut.

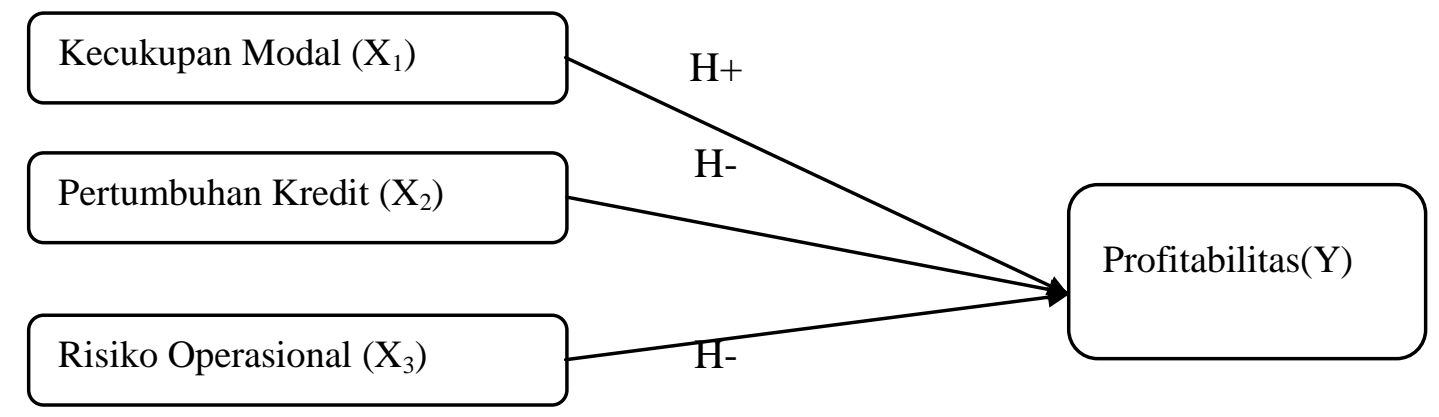

Gambar 1. Kerangka Konseptual

Tingkat kecukupan modal adalah perbandingan antara total modal dengan Aktiva Tertimbang Menurut Risiko (ATMR). Modal merupakan faktor yang sangat penting bagi perkembangan kemajuan LPD. Jumlah modal yang ada dalam suatu LPD mencerminkan kemampuan menutup risiko kerugian LPD, serta mencerminkan kesehatan lembaga yang bertujuan untuk menjaga kepercayaan 
masyarakat kepada perbankan, melindungi dana masyarakat pada lembaga bersangkutan dan untuk memenuhi ketetapan standar BIS yang menjadi suatu persyaratan yang penting bahkan wajib didalam meningkatkan pertumbuhan LPD. Dengan permodalan yang kuat akan mampu menjaga kepercayaan masyarakat terhadap bank yang bersangkutan, sehinggamasyarakatpercayauntuk menghimpun dana kepada bank tersebut, dana yang dihimpun tersebut kemudian disalurkan kembali oleh LPD kepada masyarakat melalui kredit. Jumlah modal minimal harus ada dalam sebuah LPD karena bertujuan untuk meniadakan atau meminimalkan risiko yang mungkin terjadi, apabila LPD tidak memiliki jumlah modal minimum dalam kondisi tertimpa risiko maka LPD akan sulit dioperasikan dengan baik, secara otomatis tidak berpengaruh terhadap profitabilitas. Hasil penelitian yang dilakukan oleh Maha (2011) menunjukkan tingkat kecukupan modal berpengaruh signifikan terhadap profitabilitas.

$\mathrm{H}_{1}$ : Kecukupan modal berpengaruh positif pada profitabilitas LPD di KabupatenGianyar.

Pertumbuhan kredit menggambarkan tingkat perkembangan volume kredit yang disalurkan kepada pihak ketiga dalam periode tertentu. Semakin tinggi pertumbuhan kredit maka semakin baik kualitas dan kuantitas kredit dan semakin tinggi kesempatan LPD untuk menyalurkan kembali dana tersebut kepada masyarakat atau debitur, sehingga kesempatan memperoleh laba semakin besar. Meningkatnya pertumbuhan kredit akan menyebabkan bertambahnya pendapatan yang diperoleh LPD dari pembayaran bunga. Pendapatan bunga merupakan salah satu pendapatan operasional yang diperoleh LPD. Penelitian Rastiniyati (2015) 
Kadek Damawan dan I Wayan Suartana. Tingkat...

menemukan bahwa pertumbuhan kredit berpengaruh positif terhadap profitabilitas.

$\mathrm{H}_{2}$ : Pertumbuhan kredit berpengaruh positif pada profitabilitas LPD di Kabupaten Gianyar

Rasio BOPO menunjukan efisiensi Lembaga Perkreditan Desa (LPD) dalam menjalankan usaha pokoknya terutama kredit, dimana bunga kredit menjadi pendapatan terbesar Lembaga Perkreditan Desa (LPD). Pengelolaan pembiayaan sangat diperlukan oleh LPD, mengingat fungsi pembiayaan sebagai penyumbang pendapatan terbesar bagi LPD. BOPO digunakan untuk mengukur tingkat efisiensi dan kemampuan LPD dalam melakukan kegiatan operasinya (Kurnia, 2012). BOPO yang rendah menunjukan semakin tinggi efisiensi operasional yang dicapai LPD dalam menjalankan aktivitas usahanya. Jika BOPO semakin meningkat berarti biaya operasional LPD semakin besar, sehingga menyebabkan laba semakin menurun, pada akhirnya akan menyebabkan profitabilitas LPD menurun (Dito, 2011). Pendapat ini didukung oleh penelitian Yuliana (2007) dan Yogi (2013). Berdasarkan uraian tersebut dapat dapat ditarik hipotesis sebagai berikut.

$\mathrm{H}_{3}$ : Risiko operasional berpengaruh negatif pada profitabilitas LPD di KabupatenGianyar.

\section{METODE PENELITIAN}

Lokasi penelitian ini adalah Lembaga Perkreditan Desa di Kabupaten Gianyar periode 2015-2017 yang data keuangannya diperoleh dari Pembinaan Lembaga Perkreditan Desa Kabupaten (PLPDK) yang berada di kabupaten gianyar. Lokasi penelitian ini dipilih karena LPD merupakan Lembaga keuangan yang tidak diikat 
oleh peraturan Bank Indonesia sebagai bank yang mengatur kegiatan usaha perpankan, tetapi LPD diatur dan diresmikan berdasarkan Perda Provinsi Bali No. 8 Tahun 2002 dan diikat oleh pararem desa atau Peraturan Desa Adat setempat. LPD juga hanya dapat ditemukan di Bali dan pengelolaannya seluruhnya diserahkan kepada desa pekraman bersangkutan tetapi diawasi oleh badan independen yaitu PLPDK (Pengawas Lembaga Perkreditan Desa Kabupaten/Kota).

Objek penelitian ini adalah LPD-LPD yang terdapat di Kabupaten Gianyar dan terdaftar di LP LPD Kabupaten Gianyar periode 2015-2017 khususnya mengenai kecukupan modal, pertumbuhan kredit, dan risiko operasional.

Kecukupan Modal yaitu perbandingan antara total modal dengan ATMR (Aktiva Tertimbang Menurut Risiko). Tingkat kecukupan modal dapat diukur dengan rumus sebagai berikut

Tingkat kecukupan modal $=\underline{\text { Total Modal }} \times 100 \%$ ATMR

ATMR = Nilai Masing-masing Aktiva $x$ Bobot Risiko

Pertumbuhan kredit adalah perubahan penanaman dana LPD dalam bentuk pinjaman yang diberikan dari tahun 2014 sampai dengan 2017. Rumus perhitungan sebagai berikut.

$\mathrm{PK}=\underline{\text { kredit periode sekarang-kredit periode sebelumnya }} \times 100 \%$ kredit periode sebelumnya

Risiko BOPO diukur dengan membandingkan antara biaya operasional dengan pendapatan operasional LPD. Biaya operasional menunjukan biaya yang dikeluarkan oleh LPD untuk menunjang kegiatan operasionalnya. Pendapatan operasionalnya menunjukan pada hasil yang diperoleh atas 
kegiatanoperasionalnyayang telah dilakukan oleh LPD tersebut. Perhitungan rasionya sebagai berikut.

$$
\text { Rasio BOPO }=\frac{\text { Beban Operasional }}{\text { Pendapatan Operasional }} \times 100 \%
$$

Profitabilitas (Y) yaitu kemampuan perusahaan dalam memperoleh laba dari modal yang diinvestasikan. Variabel ini dapat diukur dengan rumus ROA yaitu laba setelah pajak dibagi dengan total aset.

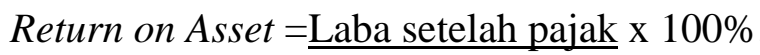

\section{Total aset}

Populasidalam penelitian ini meliputi LPD yang terdapat di Kabupaten Gianyar. Sampel yang digunakan dalam penelitian ini dipilih dengan metod epurposive sampling, yaitu metode penentuan sampel dengan pertimbangan tertentu, dimana anggota sampel akan dipilih sedemikian rupa sehingga sampel yang terbentuk dapa tmewakili sifat-sifat populasi.

Teknis analisis data yang digunakan dalam penelitian ini adalah regresi liniear berganda. Dilakukan Uji Statistik Deskriptif, Uji Asumsi Klasik, Uji Kelayakan Model Regresi hingga Uji Regresi Linear Berganda yang menghasilkan persamaan sebagai berikut.

$$
Y=\alpha+\beta_{1} X_{1}+\beta_{2} X_{2}+\beta_{3} X_{3}+e
$$

\begin{tabular}{|c|c|}
\hline Y & $=$ Profitabilitas \\
\hline$\alpha$ & $=$ Konstanta \\
\hline$\beta_{1,2,3,4}$ & $=$ Koefisien regresi dari variabel independen \\
\hline$X_{1}$ & $=$ Kecukupan Modal \\
\hline $\mathrm{X}_{2}$ & $=$ Pertumbuhan Kredit \\
\hline $\mathrm{X}_{3}$ & $=$ Risiko Operasional \\
\hline & $=$ error term \\
\hline
\end{tabular}

Keterangan : 


\section{HASIL DAN PEMBAHASAN}

Sejak pendirian LPD pada tahun 1985, yang pembentukan awalnya didirikan 8 LPD, tersebar merata di setiap kabupaten/kota, yang masing-masing digunakan sebagai pilot project Pemerintah Bali. Dari 8 pelaksanaan proyek LPD menunjukkan perkembangan dan kemajuan yang sangat signifikan, karena mendapat respon positif dan dukungan penuh dari masyarakat desa, dalam mendongkrak pertumbuhan ekonomi masyarakat desa dengan memecahkan masalah kelangkaan permodalan dan mobilitas dana masyarakat desa, guna meningkatkan usaha golongan ekonomi lemah yang banyak terdapat di daerah pedesaan.

Untuk mengantisipasi perkembangan LPD dimasa-masa yang akan datang dan menghadapai perkembangan lembaga keuangan formal secara lebih luas, maka Pemda Bali telah mengeluarkan Perda Nomor 3 Tahun 2007, yang merupakan pengganti (penyempurnaan) dari Perda Nomor 2 Tahun 1988, tentang Lembaga Perkreditan Desa (LPD).Populasi dalam penelitian ini adalah LPD di Kabupaten Gianyar yang berjumlah 269 LPD. Berdasarkan metode purposive sampling 114 LPD yang memenuhi kriteria dan dijadikan sampel.

Statistik deskriptif memberikan informasi mengenai karakteristik variabel penelitian berupa nilai rata-rata (mean), deviasai standar (standard deviation), dan nilai maksimum-minimum. Hasil statistik deskriptif dalam penelitian ini disajikan pada Tabel 2 sebagai berikut. 
Tabel 2.

Hasil Analisis Statistik Deskriptif

\begin{tabular}{lrrrrr}
\hline & N & Minimum & Maximum & Mean & Std. Deviation \\
\hline X1 & 213 & 0,1400 & 0,5700 & 0,3427 & 0,0958 \\
X2 & 213 & 0,0010 & 1,9300 & 0,1872 & 0,2371 \\
X3 & 213 & $-0,8680$ & 2,2503 & 0,2172 & 0,2824 \\
Y & 213 & $0.00350,9505$ & 0,7506 & 0,1427 \\
Valid N (listwise) & 213 & & & & \\
\hline
\end{tabular}

Sumber: Data diolah, 2018

Berdasarkan Tabel 2 terlihat bahwa nilai minimum profitabilitas adalah sebesar 0.014, yang diperoleh oleh LPD Gentong, nilai maksimum sebesar 0.057 yang diperoleh oleh LPD Lodtunduh dan nilai rata-rata sebesar 0,342770. Standar deviasi untuk profitabilitas adalah 0,0958494. Hal ini berarti bahwa berdasarkan hasil statistik deskriptif terjadi perbedaan nilai profitabilitas yang diteliti terhadap nilai rata-ratanya sebesar 0,09548494 .

Variabel Kecukupan Modal memiliki nilai minimum sebesar 0,0010, yang diperoleh oleh LPD Cebok nilai maksimum sebesar 1,9300 yang diperoleh oleh LPD Lodtunduh dan nilai rata-rata sebesar 0,187282 Standar deviasi untuk variabel kecukupan modal sebesar 0,2371076 Hal ini berarti bahwa berdasarkan hasil statistik deskriptif terjadi perbedaan nilai kecukupan modal yang diteliti terhadap nilai rata-ratanya yaitu sebesar 0,2371076 .

Variabel Pertumbuhan Kredit memiliki nilai minimum sebesar $-0,8680$ yang diperoleh oleh LPD Cebok dan nilai maksimum sebesar 2,2503 yang diperoleh oleh LPD Lodtunduh dan nilai rata-rata sebesar 0,217237. Standar deviasi untuk variabel pertumbuhan kredit sebesar 0, 2824659. Hal ini berarti bahwa berdasarkan hasil statistik deskriptif terjadi perbedaan nilai pertumbuhan kredit yang diteliti terhadap nilai rata-ratanya yaitu sebesar 0, 2824659. 
Variabel risiko operasional memiliki nilai minimum sebesar 0,035, yang diperoleh oleh LPD Batur Sari dan nilai maksimum sebesar 0.9505 yang diperoleh oleh LPD Blesela dan nilai rata-rata sebesar 0,750738. Standar deviasi untuk variabel manajemen risiko sebesar 0,1427887. Hal ini berarti bahwa berdasarkan hasil statistik deskriptif terjadi perbedaan nilai manajemen risiko yang diteliti terhadap nilai rata-rata yaitu sebesar 0,1427887.

Selanjutnya uji asumsi klasik yang meliputi uji normalitas, heteroskedastisitas, dan multikolinearitas. Diperoleh dengan menggunakan uji Kolmogorov-Smirnov dengan signifikansi lebih besar dari 0,05 yaitu 0,096, maka dapat disimpulkan bahwa data terdistribusi secara normal.Nilai DW sebesar 1,963. Nilai dU untuk jumlah sampel 213 dengan 3 variabel bebas adalah 1,799. Maka nilai 4 - dU adalah 2,201. Oleh karena nilai d statistic 1,963 berada diantara dU dan 4-dU maka pengujian dengan Durbin-Watsom berada pada daerah tidak ada autokorelasi maka ini berati pada model regresi tidak terjadi gejala autokorelasi.Seluruh variabel bebas memiliki nilai VIF tidak lebih dari 10 dan mempunyai angka tolerance tidak kurang dari 0,1 . Hal ini berati bahwa tidak ada gejala multikolinier dari model regresi yang dibuat.Kemudian semua variabel memiliki Asymp. Sig ( $\mathrm{p}$ value) $>0,05$, artinya pada model regresi tidak terdapat heteroskedastisitas.

Setelah semua asumsi klasik terpenuhi, maka selanjutnya memaparkan hasil analisis regresi linier berganda diperoleh hasil yang ditunjukan pada Tabel 3 berikut. 
Tabel 3.

Hasil Analisis Regresi Linier Berganda

\begin{tabular}{cccccc}
\hline Variabel & Unstandardized Beta & Std. Error & $\begin{array}{c}\text { Standarized } \\
\text { Beta }\end{array}$ & T hitung & Sig. uji t \\
\hline (Constant) & 0,338 & 0,034 & & 10,070 & 0,000 \\
X1 & 0,720 & 0,026 & 0,177 & 2,758 & 0,006 \\
X2 & 0,109 & 0,022 & 0,320 & 4,995 & 0,000 \\
X3 & $-0,043$ & 0,043 & $-0,063$ & $-0,996$ & 0,032 \\
& & & & & \\
\hline
\end{tabular}

Sumber: Data diolah, 2018

Berdasarkan hasil analisis regresi linier berganda seperti yang disajikan pada Tabel 3, maka dapat dibuat persamaan regresi sebagai berikut:

$$
\mathrm{Y}=0,338+0,720 \mathrm{X}_{1}+0,109 \mathrm{X}_{2}-0,043 \mathrm{X}_{3}+e
$$

Dari hasil uji Anova atau F test didapatkan hasil bahwa nilai $\mathrm{F}$ sebesar 13,464 dengan probabilitas 0,000 . Karena probabilitas $<0,05$ maka model regresi dapat digunakan untuk memprediksi tingkat kecukupan modal, pertumbuhan kredit dan risiko opersional. Hal ini menunjukan bahwa model ini layak digunakan untuk dianalisis. Untuk dapat mengetahui seberapa besar pengaruh kecukupan modal, pertumbuhan kredit dan manajemen risiko memengaruhi profitabilitas, dapat dilihat dari nilai koefisien adjusted R2 adalah 0,141 hal ini berarti $14,1 \%$ variasi profitabilitas dapat dijelaskan oleh variasi dari tiga variabel independen yaitu kecukupan modal, Pertumbuhan kredit dan risiko operasional. Sedangkan sisanya 85,9\% (100\%-14,1\%) dijelaskan oleh faktor lain diluar model.

Hipotesis pertama $\left(\mathrm{H}_{1}\right)$ menyatakan bahwa kecukupan modal berpengaruh positif pada profitabilitas LPD di Kabupaten Gianyar. Berdasarkan tabel 4.4 diperoleh nilai t hitung untuk variabel motivasi kualitas sebesar 2,758, nilai 
signifikansi uji t sebesar 0,006 yang lebih kecil dari $\alpha=0,05$ dan nilai koefisien regresi sebesar 0,072. Hasil uji statistik tersebut menunjukkan bahwa H1 diterima yang artinya semakin besar modal yang dimiliki oleh LPD maka profitabilitasnya juga akan semakin besar.

Hasil ini juga didukung dengan penelitian sebelumnya dari Mas (2010) dan Maha (2011) yang menyatakan bahwa tingkat kecukupan modal berpengaruh signifikan terhadap Profitabilitas. Selain itu, penelitian yang dilakukan dwikayanti (2014) juga mendukung hasil dari penelitian ini bahwa kecukupan modalberpengaruh positif pada profitabilitas LPD. Berdasarkan penelitian terdaluhu dan hasil penelitian ini dapat disimpulkan bahwa semakin besar modal yang dimiliki oleh LPD maka profitabilitas juga akan meningkat.

Hipotesis kedua $\left(\mathrm{H}_{2}\right)$ menyatakan bahwa pertumbuhan kredit berpengaruh positif pada profitabilitas LPD di Kabupaten Gianyar. Berdasarkan tabel 4.4 diperoleh nilai t hitung untuk variabel motivasi kualitas sebesar 4,995, nilai signifikansi uji t sebesar 0,000 yang lebih kecil dari $\alpha=0,05$ dan nilai koefisien regresi sebesar 0,109. Hasil uji statistik tersebut menunjukkan bahwa $\mathrm{H} 2$ diterima yang berartipertumbuhan kredit memiliki hubungan yang searah dengan profitabilitas sehingga saat pertumbuhan kredit mengalami peningkatan tanpa adanya kredit macet yang diderita LPD di Kabupaten Gianyar, maka profitabilitas juga akan mengalami pertumbuhan.

Hasil ini juga didukung dengan penelitian sebelumnya dari Rastiniyati (2015) yang menyatakan bahwa tingkat pertumbuhan kredit berpengaruh signifikan terhadap Profitabilitas. Berdasarkan penelitian terdaluhu dan hasil 
penelitian ini dapat disimpulkan bahwa saat pertubuhan kredit mengalami peningkatan tanpa adanya kredit macet yang diderita LPD di Kabupaten Gianyar, maka profitabilitas juga akan mengalami pertumbuhan.

Hipotesis ketiga $\left(\mathrm{H}_{3}\right)$ menyatakan bahwa risiko opersional yang diproksikan dengan BOPO berpengaruh negatif pada profitabilitas LPD di Kabupaten Gianyar. Berdasarkan hasil olahan SPSS yang termuat dalam Tabel 4.11 dinyatakan nilai $\mathrm{p}$ - value untuk variabel manajemen risiko sebesar $0,032<\alpha$ $=0,05$ maka H3 diterima. Secara teori BOPO bertujuan untuk mengetahui tingkat operasional yang dihitung berdasarkan perbandingan antara biaya operasional dalam 12 bulan terhadap pendapatan operasional dalam periode yang sama (Suputra, 2017). Riyadi (2010:161) jika tingkat rasio BOPO ini berada pada angka diatas $90 \%$ dan mendekati 100\% maka kinerja bank (dalam hal ini LPD) tersebut menunjukan tingkat efisiensi yang rendah, namun jika tingkat rasio ini mendekati angka 75\% menandakan kinerja bank tersebut menunjukan tingkat efisiensi yang tinggi.

Pertumbuhan risiko operasional yang diproksikan dengan BOPO pada profitabilitas LPD berarti apabila terjadi peningkatan terhadap BOPO maka profitabilitas LPD akan menurun. Berdasarkan data BOPO LPD di Kabupaten Gianyar periode 2015-2017 bahwa rasio BOPO rata-rata dibawah 90\%. Hal ini dapat diartikan bahwa LPD yang ada di Kabupaten Gianyar sudah efisien dalam melaksanakan kegiatannya.

Secara teori penetapantujuan dimana dalam pencapaian tujuan perusahaan terdapat dimensi partisipasi tujuan dimana, semakin rendah tingkat 
BOPO suatu perusahaan maka semakin efisiensi perusahaan sehingga pihak internal maupun sumber daya manusia pada perusahaan turut berpartisipasi pada pencapaian tujuan perusahaan (Greydi, 2013). Berdasarkan dari pembahasan hasil penelitian, maka dapat dinyakatan bahwa secara keseluruhan manajemen risiko berpengaruh negatif pada kinerja keuangan koperasi di Kabupaten Gianyar. Hasil penelitian ini mendukung penelitian yang dilakukan oleh Yuliani (2007) dan Yogi (2013).

Modal merupakan faktor yang sangat penting bagi perkembangan kemajuan LPD. Jumlah modal yang ada dalam suatu LPD mencerminkan kemampuan menutup risiko kerugian LPD, serta mencerminkan kesehatan lembaga yang bertujuan untuk menjaga kepercayaan masyarakat kepada LPD. Ini terbukti pada penelitian ini yang menunjukan kecukupan modal berpengaruh positif pada profitabiltas LPD di kabupaten Gianyar. Hal ini mengandung implikasi agar Lembaga Perkreditan Desa kedepannya mampu mempertahankan modal yang cukup sehingga mampu menjaga kestabilan keuangan dan menjaga kepercayaan masyarakat terhadap LPD yang bersangkutan. Adanya struktur modal yang kuat menimbulkan kepercayaan masyarakat untuk menyertakan dana pada LPD tersebut.

Kredit merupakan faktor yang sangat penting bagi perkembangan kemajuan LPD, karena bunga yang dihasilkan merupakan pendapatan bagi LPD itu sendiri. Pertumbuhan kredit yang meningkat tanpa adanya kredit macet akan mendongkrak profitabilitas LPD tersebut. Hasil penelitian inimenunjukkan bahwa pertujmbuhan kredit berpengaruh positif terhadap profitabilitas LPD. 
Hasil penelitian ini sejalan dengan penelitian yang dilakukan Athanasoglau et al (2008) yang menyatakan bahwa profitsbilitas suatu Lembaga keuangan akan meningkat seiring dengan jumlah pertumbuhan kredit yang dikelola secara baik.

Beban Operasional Pendapatan Operasional (BOPO) merupakan rasio yang digunakan sebagai proksi dalam mengukur manajemen risiko. BOPO membandingkan antara biaya operasional terhadap pendapatan operasional guna memperoleh gambaran mengenai kemampuan dari pihak LPD dalam mengendalikan profitabilitasnya. Hasil penelitian ini menunjukan bahwa manajemen risiko yang diproksikan dengan BOPO berpengaruh negatif pada profitabilitas LPD di Kabupaten Gianyar. Hal ini menunjukkan bahwa LPD yang ada di Kabupaten Gianyar dalam mengelola pendapatan operasionalnya sudah cukup baik. Hal ini mengandung implikasi supaya seluruh LPD menerapkan manajemen risiko khususnya BOPO agar LPD mampu menjaga kestabilan profitabilitas setiap tahunnya. Rasio BOPO yang rendah menunjukkan beban operasional LPD tersebut rendah terhadap pendapatan operasionalnya, dengan kata lain pendapatan yang diperoleh LPD lebih besar dibandingkan dengan beban opersionalnya.

\section{SIMPULAN}

Berdasarkan pada hasil analisis dan data dan pembahasan pada bab sebelumnya mengenai pengaruh kecukupan modal pertumbuhan kredit dan risiko operasional pada profitabilitas LPD di Kabupaten Gianyar, maka dapat dapat disimpulkan beberapa hal antara lain. 1). Kecukupan modal berpengaruh positif pada 
profitabilitas Lembaga Perkreditan Desa (LPD) di Kabupaten Gianyar; 2). Pertumbuhan kredit berpengaruh positif pada profitabilitas LPD kabupaten Gianyar; 3). Risiko Operasional berpengaruh negative pada profitabilitas LembagaPerkreditan Desa (LPD) di Kabupaten Gianyar.

Saran yang dapat diberikan yakni LPD memiliki peranan yang sangat penting dalam perekonomian di Indonesia khususnya di Bali. Selain mempertimbangkan hukum adat (awig-awig) dalam kegiatan operasionalnya, diharapkan LPD pengaruh kecukupan modal, pertumbuhan kredit, dan manajemen risiko yang dapat meningkatkan kinerja keuangannya. Maka disarankan kepada seluruh LPD di seluruh Bali jugamenerapkan kecukupan modal, pertumbuhan kredit, dan manajemen risiko yang handal demi kelangsungan LPD kedepannya.Bagi pihak pengurus LPD disarankan untuk meningkatkan pertumbuhan kredit dan menekan nilai BOPO agar tidak tergolong dalam LPD dalam perhatian khusus.

\section{REFERENSI}

Ariestya, Putu Yutika dan Ardiana, Putu Agus. 2016. Implementasi Good Corporate Governance pada Kinerja Perusahaan Sektor Keuangan dengan Manajemen Risiko sebagai Variabel Intervening. Jurnal Fakultas Ekonomi dan Bisnis Universitas Udayana.

Bratland, Jhon. 2010. Capital Concepts as Insights into the Maintenance and Neglect of Infratruckture. The Independent Review. Oakland. 15 (1):h:36.

Hakim, Aditya Rahman. 2009. Pengaruh Pertumbuhan Dana Pihak Ketiga dan Aktiva Produktif Terhadap Net Interest Margin pada Bank Pemerintah.

Maha Trisna Yunita, Luh Ketut.2010. Pengaruh Tingkat Perputaran Kas, Tingkat Kecukupan Modal, Loan to Deposit Ratio, Dan Tingkat Pertumbuhan Jumlah Nasabah Pada Profitabilitas Lembaga Perkreditan Desa (LPD) 
Kecamatan Buleleng Periode 2008 - 2010 .E-Journal Fakultas Ekonomi Universitas Udayana, Bali.

Matrisyasi Dewi, Ni Putu. 2010. Pengaruh Pertumbuhan Perusahaan, Tingkat Perputaran Kas, Tingkat Pertumbuhan Jumlah Nasabah, Leverage Management Dan Spread Management Pada Profitabilitas Lembaga Perkreditan Desa (LPD) Kabupaten Badung Selatan. EjournalSarjana Akuntansi Fakultas Ekonomi Universitas Udayana, Bali.

Obicks Wintara. 2010. Pengaruh Tingkat Perputaran Kas, Loan to Deposit Ratio dan Tingkat Kecukupan Modal pada Rentabilitas Ekonomis Lembaga Perkreditan Desa (LPD) Kota Denpasar. E-Journal Sarjana Akuntansi Fakultas Ekonomi Universitas Udayana, Bali.

Prasetyo Dewi Agung, Ni Putu Ayu Darmayanti. 2012. "Pengaruh Risiko Kredit, Likuiditas, Kecukupan Modal, dan Efisiensi operasional terhadap Profitabilitas PT. BPD Bali”. E-Journal Sarjana Akuntansi Fakultas Ekonomi Universitas Udayana, Bali.

Rastiniyati, Ni Kadek dan Ulupui I.G.K.A. 2015. Pengaruh pertumbuhan kredit pada profitabilitas dengan tingkat perputaran kredit sebagai variabel pemoderasi. E-Journal Akuntansi Universitas Udayana. ISSN: 23028556

Samina Riaz, 2013. Profitability Determinants of Commercial Banks in Pakistan. Proceeding of 6th International Bussiness and Social Sciences Research Conference.

Surata, I Nyoman. 2011. Penerapan Sanksi Adat Oleh Desa Pakraman Dalam Pengelolaan Lembaga Perkreditan Desa (LPD). Widyatech Jurnal Sains Dan Teknologi 1(1).

Vong, P. L. and Chan, H. S. (2009). Determinants of Bank Profitability in Macau Monetary Research Bullletin, 12, hal. 93-113.

Yogi, Prasanjaya. 2013. Analisis Pengaruh Rasio CAR, BOPO, LDR dan Ukuran Perusahaan Terhadap Profitabilitas Bank Yang Terdaftar di BEI. EJournal Sarjana Akuntansi Fakultas Ekonomi Universitas Udayana. 